\title{
Hydrochemical Characteristics, Quality Assessment and Solute Source Identification of Coal Bearing Fractured Aquifer in Dingji Coal Mine, Huainan Coalfield, China
}

\author{
Jie Ma*(**)†, Jianghong Wang***, Song Chen*(**), Hongbao Dai****, Jingyu Zhao*(**), Haitao Zhang*(**) and \\ Zhichun Li**** \\ *School of Resources and Civil Engineering, Suzhou University, Suzhou, Anhui, China \\ **Key Laboratory of Mine Water Resource Utilization of Anhui Higher Education Institute, Suzhou, Anhui, China \\ ***Dingji Coal Mine of Huaihu Coal Power Co., Ltd, Huainan, Anhui, China \\ ****School of Environment and Surveying Engineering, Suzhou University, Suzhou, Anhui, China \\ $\dagger$ Corresponding author: Jie Ma; ahszumajie@163.com
}

Nat. Env. \& Poll. Tech.

Website: www.neptjournal.com

Received: 11-10-2020

Revised: $15-12-2020$

Accepted: 13-01-2021

Key Words:

Solute source

Hydrochemical facies

WQI

Irigation assessment

Multivariate analysis

\begin{abstract}
Coal-bearing fractured aquifer is regarded as one of the most dynamic mine water inrush sources, and after pumping and treating, it can be used as a water supply for coal mine production, coal preparation plant, rural irrigation, and even reserved drinking water source. Hence, this study focuses on the hydrochemical characteristics, ion source, and water quality evaluation with respect to drinking and irrigation of the coal-bearing fractured aquifer in Dingji coal mine, Huainan coalfield, China. Descriptive statistics and hydrochemical classification diagrams including the Piper diagram and Chadha rectangular diagram were carried out to depict the hydrochemical characteristics and facies. The water quality of the aquifer was assessed for irrigation and drinking purposes using the WHO threshold value, water quality index (WQI), SAR, \% Na and RSC. Hydrochemical formation mechanism and solute origin of major ions were explained by Gibbs diagram, bivariate diagrams, and multivariate statistical analysis. The results show that the dominant hydrochemical facies are the $\mathrm{Cl}-\mathrm{Na}$ type and the $\mathrm{HCO}_{3}-\mathrm{Na}$ type. The sequence of ions is $\mathrm{Na}^{+}>\mathrm{Ca}^{2+}>\mathrm{Mg}^{2+}$ for cations, and $\mathrm{HCO}_{3}{ }^{-}>\mathrm{Cl}^{-}>\mathrm{SO}_{4}{ }^{2-}>$ $\mathrm{CO}_{3}{ }^{2-}$ for anions. The main solute sources are controlled by various factors including the dissolution of halite, sulfate, and carbonate rocks, the weathering of silicate, and cation exchange. Water quality assessment based on WQI suggests that none of the samples fall under the excellent category, even $32.5 \%$ is not suitable for direct drinking. Meanwhile, the samples of the aquifer are generally unsuitable for irrigation. Before utilization for irrigation and even drinking, appropriate water treatment should be applied to guarantee its security during usage.
\end{abstract}

\section{INTRODUCTION}

Since the $21^{\text {st }}$ century, with the rapid development of economics and changes in the global environment, mankind is being confronted with even more environmental pollution, climate warming, ecological degradation, and water resources shortage, etc.

Coal resource exploitation accounts for more than $75 \%$ of China's energy production (Liu et al. 2007). With the increasing mining depth and usage demand, mine hazards such as water, fire, dust, gas, and roof have become more dynamic and disastrous, inducing huge economic losses and massive casualties. Among these, water inrushes always occur owing to complicated geologic and hydrogeological conditions. For a long time, scholars and specialists in the prevention and control of mine water disasters have focused on how to ensure production safety and avoid stoppages, casualties, and repeated economic losses. In recent decades, many researchers have offered efficient and effective ways to reduce the mine geological hazards (Gui \& Lin 2016, Mahato et al. 2018). Meanwhile, relevant scholars have taken an interest in mine water treatment and resource utilization research, providing technical and theoretical support for safe, green, and efficient mining (Zhang et al. 2020, Sun et al.2020, Gu 2015, Jiang et al. 2018).

The research scopes of mine water prevention and controlling have been conducted from the initial hydro-geological and hydro-chemical conditions appraisal, and gradually involved the coupling analysis of the hydro-chemical field, hydro-dynamic field, water temperature field, and others. In addition, assessment of drinking water, irrigation evaluation, and water inrush identification are also hot topics in 
mine water research. In view of the sustainable utilization of water resources, and prevention and controlling of water inrush, the objectives of this study were to: (1) analyze the hydrochemical characteristics and types of the coal-bearing aquifer, (2) appraise and understand the water quality for irrigation and drinking, (3) explain the mechanism of water-rock interactions and identify the solute sources of major ions.

\section{BACKGROUND OF STUDY AREA}

\section{Location and climate}

The Dingji mine is a new type of coal mine with the integration of coal and electricity, which is affiliated to Huaihu Coal Power Co., Ltd. The study area is situated in Huainan coalfield with coal production of 6 million tons per year, and lies between latitudes $32^{\circ} 47^{\prime} 26^{\prime \prime}-32^{\circ} 54^{\prime} 31^{\prime \prime}$ and longitudes $116^{\circ} 32^{\prime} 53^{\prime \prime}-116^{\circ} 42^{\prime} 37^{\prime \prime}$ (Fig. 1). It approximately extends $12-15 \mathrm{~km}$ long from east to west and $4-11 \mathrm{~km}$ wide from north to south, covering a total area of around $95.7 \mathrm{~km}^{2}$. The coal mine is located in the midstream of the Huaihe River, and the altitudes range between $21 \mathrm{~m}$ and $23 \mathrm{~m}$ above mean sea level, with a terrain tendency of high in the northwest and low in the southeast.

The study area belongs to a semi-humid climate and has four distinct seasons, warm in spring, hot in summer, cool in autumn, and cold in winter. According to Fengtai
County Meteorological Bureau's data, the average annual temperature is $15.1^{\circ} \mathrm{C}$, with a maximum value of $41.4{ }^{\circ} \mathrm{C}$ and a minimum value of $-22.8^{\circ} \mathrm{C}$. Annual precipitation and evaporation are $320.44 \mathrm{~mm}$ and $1610.14 \mathrm{~mm}$, respectively. The rainfall season is concentrated from June to August.

\section{Geology and hydrogeology}

Huainan coalfield is located in the southeast of the North China Plate. The regional notable structure form is a synclinorium, and the Dingji coal mine lies in the middle-north part. The overall structural form of the mine is a monocline structure inclined to the east, and the formation dip is gentle. Basic fine-grained rock and syenite porphyry among Yanshanian intrusion are well developed, with a maximum thickness of $87.87 \mathrm{~m}$.

From the bottom to top, the strata of the coal mine, as evidenced by huge drillings, mainly consists of Ordovician $\left(\mathrm{O}_{1+2}\right)$, Carboniferous $\left(\mathrm{C}_{2}\right.$ and $\left.\mathrm{C}_{3}\right)$, Permian $\left(\mathrm{P}_{1 \mathrm{~s}}, \mathrm{P}_{1 \mathrm{x}}, \mathrm{P}_{2 \mathrm{~s}}\right.$, and $\left.\mathrm{P}_{2 \mathrm{sj}}\right)$, Triassic $(\mathrm{T})$, Paleogene $(\mathrm{E})$, Neogene $(\mathrm{N})$ and Quaternary (Q). The mid-lower Ordovician Majiagou formation $\left(\mathrm{O}_{1+2}\right)$ consisted of limestone and dolomitic limestone with breccias limestone and shale, and the maximum exposure thickness by drilling is $93.42 \mathrm{~m}$. The middle Carboniferous Benxi formation $\left(\mathrm{C}_{2}\right)$ is composed mainly of mudstone and aluminous mudstone, the upper Carboniferous Taiyuan formation $\left(\mathrm{C}_{3}\right)$ comprises 12 to 13 layers of thin limestone and

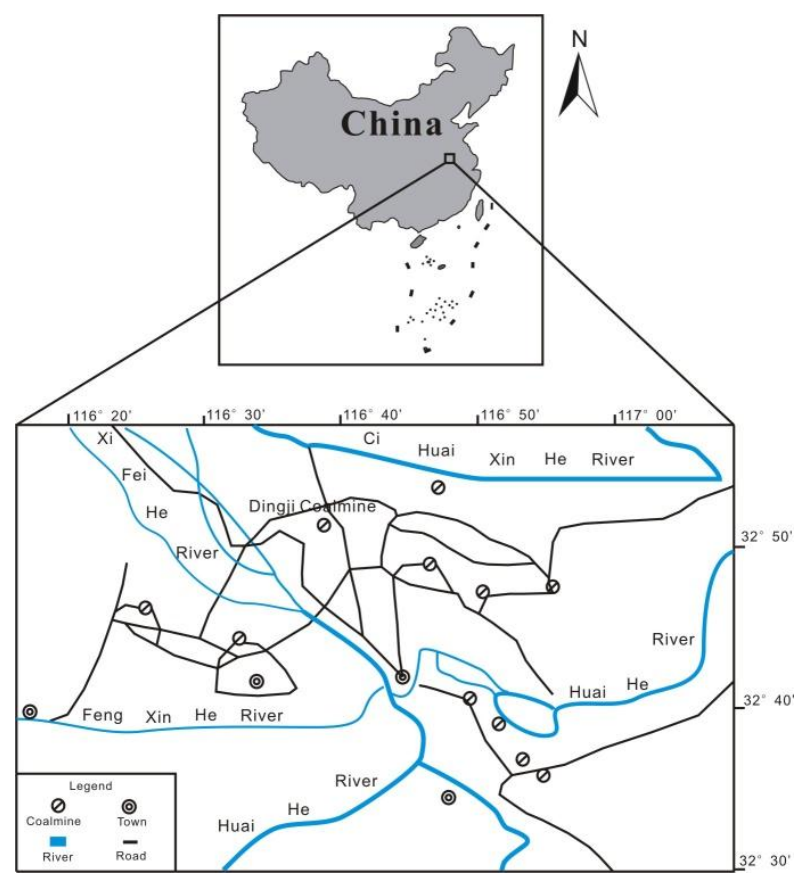

Fig. 1: Location of the study area (Dingji Coal mine). 
some intercalations, such as mudstone and sandstone. The average thickness of the two formations is $7.18 \mathrm{~m}$ and 110.27 $\mathrm{m}$, respectively. The lower Permian Shanxi formation $\left(\mathrm{P}_{1 \mathrm{~s}}\right)$, the lower Xiashihezi formation $\left(\mathrm{P}_{1 \mathrm{x}}\right)$, the Upper Shangshihezi formation $\left(\mathrm{P}_{2 \mathrm{~s}}\right)$, and the Upper Sunjiagou formation $\left(\mathrm{P}_{2 \mathrm{sj}}\right)$ is about $81 \mathrm{~m}, 135 \mathrm{~m}, 510 \mathrm{~m}$, and $260 \mathrm{~m}$ thick, respectively. The Permian formation lithology is mainly composed of sandstone with different particle sizes and mudstone. The Triassic Series is made up of purplish-red sandstone, siltstone, and mudstone, and its thickness is unknown. The Paleogene Series consisted of motley glutenite, the Neogene Series comprised argillaceous conglomerate, clay, and medium sand, and the Quaternary sediment composed of silty sand, fine sand, and sandy clay.

According to lithologic characteristics, hydraulic connection, and pump testing, from shallow to deep, the main groundwater system can be divided into three types: loose porous aquifer, coal-bearing fractured aquifer, and karst fractured aquifer. The shallow part of the loose porous aquifer is recharged by precipitation and lateral inflow of surface rivers. The deep part of the loose porous aquifer confined by water-resisting lays has a limited recharge and water content is mainly static reserves. Similarly, due to the effective water-resisting lays, the water abundance of the coal-bearing fractured aquifer is primarily static reserves, and the unit water flow is $6.76 \times 10^{-4}-3.48 \times 10^{-2} \mathrm{~L} .(\mathrm{s} \cdot \mathrm{m})^{-1}$. With a large thickness of hidden strata, the karst fractured aquifer belongs to a relatively enclosed confined aquifer. By now, ten water bursting accidents have occurred in the coal mine. The sources of water inrush are mainly coal-bearing fractured aquifer and loose porous aquifer, and the water bursting volume is about $10-130 \mathrm{~m}^{3} \cdot \mathrm{h}^{-1}$.

\section{MATERIALS AND METHODS}

\section{Sampling and Measurements}

In this study, 40 coal-bearing fractured aquifer samples were collected from the water inrush points of the roadway. To guarantee the accuracy and reliability of the hydrochemical analysis, before sampling, each in-situ sample was rinsed
3-5 times with the groundwater to be collected and the sampling container was white pollution-free plastic bottles. All collection, treatment, preservation, and analytic standard methods referred to technical requirements for hydrochemistry approach in coal mine water control of Ministry of Coal Industry Standard of the People's Republic of China (MT/T 672-1997), and the hydrochemical indicator test was conducted by the Gas and Water Quality of Rescue Team of Huai-he River Energy Group Coal Company, which has participated in national mine rescue works. The selected parameters for the analysis included the total dissolved solids (TDS), $\mathrm{pH}$, and major ions $\left(\mathrm{SO}_{4}{ }^{2-}, \mathrm{Cl}^{-}, \mathrm{CO}_{3}{ }^{2-}, \mathrm{HCO}_{3}{ }^{-}, \mathrm{Ca}^{2+}\right.$, $\mathrm{Mg}^{2+}$ and $\mathrm{Na}^{+}$).

\section{Methods}

For this study, MyStat 12.0 was applied for the descriptive statistics. Correlation analysis, Piper diagram, and Chadha rectangular diagram were used to determine the hydrochemical type of the samples. Gibbs diagram and bivariate diagrams were employed to explain the mechanism of solute formation and ion source. WHO standard, water quality index (WQI), \% Na, and RSC were carried out for both drinking and irrigation evaluation. In addition, with the help of SPSS 16.0, multivariate statistical methods including cluster analysis and principal component analysis/factor analysis, known as effective tools for minimizing the effects of measurement unit difference and interpreting the hidden factors accounting for the various parameters, were conducted to further delineate the solute composition of the coal-bearing fractured aquifer.

\section{RESULTS AND DISCUSSION}

\section{Major Ion Concentration}

The physicochemical parameters and major ion compositions were summarized in Table 1, including the minimum, maximum, mean, coefficient of variation and standard deviation. Among the cations, the concentration of $\mathrm{Ca}^{2+}, \mathrm{Mg}^{2+}$ and $\mathrm{Na}^{+}$ were in the range of 1.6-32.1, 0.0-15.6, 304.9-2680.6 mg.L $\mathrm{L}^{-1}$, respectively. The concentration range of $\mathrm{CO}_{3}{ }^{2-}, \mathrm{HCO}_{3}{ }^{-}, \mathrm{Cl}^{-}$ and $\mathrm{SO}_{4}{ }^{2-}$ were 0.0-264.0, 353.9-3295.1, 45.0-2442.5 and

Table 1: Physicochemical parameters and major ion composition (expressed in $\mathrm{mg} / \mathrm{L}$, except $\mathrm{pH}$ ).

\begin{tabular}{|c|c|c|c|c|c|c|c|c|c|}
\hline Statistics & $\mathrm{Ca}^{2+}$ & $\mathrm{Mg}^{2+}$ & $\mathrm{Na}^{+}$ & $\mathrm{CO}_{3}{ }^{2-}$ & $\mathrm{HCO}_{3}^{-}$ & $\mathrm{Cl}^{-}$ & $\mathrm{SO}_{4}{ }^{2-}$ & TDS & $\mathrm{pH}$ \\
\hline Min & 1.6 & 0.0 & 304.9 & 0.0 & 353.9 & 45.0 & 1.4 & 873.6 & 8.0 \\
\hline Max & 32.1 & 15.6 & 2680.6 & 264.0 & 3295.1 & 2442.5 & 234.4 & 6320.5 & 9.3 \\
\hline Mean & 8.9 & 4.1 & 1382.4 & 54.0 & 1660.9 & 965.7 & 55.8 & 3301.5 & 8.7 \\
\hline SD & 6.9 & 3.9 & 568.1 & 63.7 & 978.4 & 405.4 & 68.3 & 1306.0 & 0.3 \\
\hline $\mathrm{CV}$ & 0.78 & 0.96 & 0.41 & 1.18 & 0.59 & 0.42 & 1.22 & 0.40 & 0.03 \\
\hline
\end{tabular}


1.4-234.4 mg. $\mathrm{L}^{-1}$, respectively. According to the average value, the relative order was $\mathrm{Na}^{+}>\mathrm{Ca}^{2+}>\mathrm{Mg}^{2+}$ for cations, and $\mathrm{HCO}_{3}{ }^{-}>\mathrm{Cl}^{-}>\mathrm{SO}_{4}{ }^{2-}>\mathrm{CO}_{3}{ }^{2-}$ for anions.

The coal-bearing fractured aquifer showed a slightly alkaline nature with an average of 8.7. The TDS values of the samples varied from 873.6 to $6320.5 \mathrm{mg} . \mathrm{L}^{-1}$, with a mean content of $3301.5 \mathrm{mg} . \mathrm{L}^{-1} .50 \%$ and $47.5 \%$ of the samples were categorized into brackish water (1000-3000 mg.. $\left.\mathrm{L}^{-1}\right)$ and saline water (3000-10000 mg. $\left.\mathrm{L}^{-1}\right)$, respectively. This relatively high salt content is concerned with $\mathrm{Na}^{+}$and $\mathrm{Cl}^{-}$, which indicated that the salinity of the aquifer was closely related to the prolonged water-interaction interaction.

The CVs values of most parameters (except for $\mathrm{pH}$ ), which were higher than 0.3 , showed an apparent spatial and temporal variation. Therefore, long-term exploitation and mine water pumping also have a predominant and universal effect on the solute concentrations and hydrochemical types.

Correlation analysis was conducted to evaluate the relationship between parameters of the aquifer (Table 2) using SPSS 16.0. According to the results, a strong correlation between $\mathrm{Na}^{+}-\mathrm{HCO}_{3}{ }^{-}(\mathrm{r}=0.851)$ and $\mathrm{Na}^{+}-\mathrm{Cl}^{-}(\mathrm{r}=0.810)$ were observed. This showed that the halite dissolution and the silicate weathering provided solute components, such as feldspar. Additionally, a positive correlation can be obtained between $\mathrm{Mg}^{2+}-\mathrm{Ca}^{2+}(\mathrm{r}=0.765), \mathrm{Ca}^{2+}-\mathrm{SO}_{4}{ }^{2-}(\mathrm{r}=0.569)$, and $\mathrm{Mg}^{2+}-\mathrm{SO}_{4}{ }^{2-}(\mathrm{r}=0.562)$, implying that sulfate dissolution, such as gypsum and magnesium sulfate, occurs. Besides this, a negative correlation can be observed between different parameters, such as $\mathrm{Ca}^{2+}-\mathrm{Na}^{+}(\mathrm{r}=-0.381), \mathrm{Ca}^{2+}-\mathrm{HCO}_{3}^{-}(\mathrm{r}=-$ $0.467), \mathrm{Mg}^{2+}-\mathrm{Na}^{+}(\mathrm{r}=-0.482)$, and $\mathrm{Mg}^{2+}-\mathrm{HCO}_{3}{ }^{-}(\mathrm{r}=-0.610)$, indicating that ion-exchange reactions also occurred during the interaction between water and aquifer.

\section{Hydrochemical facies}

Hydrochemical facies can be probed using the Piper diagram. As shown in Fig. 2, all samples are classified into sodium type with respect to cations, and bicarbonate and chloride type with respect to anions. $50.5 \%$ of samples can be categorized as $\mathrm{HCO}_{3}-\mathrm{Na}$ water type, remaining $49.5 \%$ samples are classified into Cl-Na water type (EI Alfy et al. 2019, Zaki et al. 2019).

Interpretation and classification of the hydrochemical type of the coal-bearing aquifer can also be conducted using the Chadha rectangular diagram (Fig. 3) (Liu et al. 2020, $\mathrm{Wu}$ et al. 2019). According to the difference in milliequivalent percentage between $\left(\mathrm{Ca}^{2+}+\mathrm{Mg}^{2+}\right)$ and $\left(\mathrm{Na}^{+}+\mathrm{K}^{+}\right)$, and $\left(\mathrm{CO}_{3}{ }^{2-}+\mathrm{HCO}_{3}^{-}\right)$and $\left(\mathrm{SO}_{4}{ }^{2-}+\mathrm{Cl}^{-}\right)$, this diagram can be divided into eight sub-fields. Results of hydrochemical data are plotted on the Chadha's diagram (Fig. 3), which is in confirmation with the output of Piper trilinear diagram, showing that the plots mainly fall under the field 7 and 8 with typical water of $\mathrm{Cl}-\mathrm{Na}$ and $\mathrm{HCO}_{3}-\mathrm{Na}$, respectively.

Overall, scatter plots of the two diagrams depicting hydrochemical facies demonstrated that the weathering of silicate and the dissolution of evaporite play a vital role in the solute composition of the aquifer.

\section{Source Identification}

The hydrochemical formation mechanism of major ions has been widely discussed by Gibbs diagrams (Shirke et al. 2020, Ahmad et al. 2019). In this study, the plots of the Gibbs diagram fall within the evaporation dominance area with respect to cations (Fig. 4a), implying that the dissolution of halite is the dominant mechanism controlling solute composition. For anions (Fig. 4b), the scatters of the Gibbs diagram disperse in both the evaporation dominance and rock dominance, suggesting water-rock interaction also plays an important role in influencing the anion content.

This interaction can be confirmed by the bivariate diagrams between ions. The $1: 1$ ratio of $\mathrm{Na} / \mathrm{Cl}$ indicates the pure dissolution of halite during water-rock interaction, and the plots display a linear relationship in the bivariate

Table 2: Correlation analysis between parameters of the aquifer $(n=40)$.

\begin{tabular}{|c|c|c|c|c|c|c|c|}
\hline & $\mathrm{Ca}^{2+}$ & $\mathrm{Mg}^{2+}$ & $\mathrm{Na}^{+}$ & $\mathrm{CO}_{3}{ }^{2-}$ & $\mathrm{HCO}_{3}^{-}$ & $\mathrm{Cl}^{-}$ & $\mathrm{SO}_{4}{ }^{2-}$ \\
\hline $\mathrm{Ca}^{2+}$ & 1.000 & & & & & & \\
\hline $\mathrm{Mg}^{2+}$ & $0.765^{* *}$ & 1.000 & & & & & \\
\hline $\mathrm{Na}^{+}$ & $-0.381^{*}$ & $-0.482^{* *}$ & 1.000 & & & & \\
\hline $\mathrm{CO}_{3}^{2-}$ & -0.232 & -0.259 & 0.301 & 1.000 & & & \\
\hline $\mathrm{HCO}_{3}^{-}$ & $-0.467^{* *}$ & $-0.610^{* *}$ & $0.851^{* *}$ & 0.055 & 1.000 & & \\
\hline $\mathrm{Cl}^{-}$ & -0.105 & -0.110 & $0.810^{* *}$ & 0.261 & $.412^{* *}$ & 1.000 & \\
\hline $\mathrm{SO}_{4}^{2-}$ & $0.569^{* *}$ & $0.562^{* *}$ & $-0.347^{*}$ & -0.153 & $-.385^{*}$ & -0.233 & 1.000 \\
\hline
\end{tabular}

**Correlation is significant at the 0.01 level (2-tailed).

*Correlation is significant at the 0.05 level (2-tailed). 

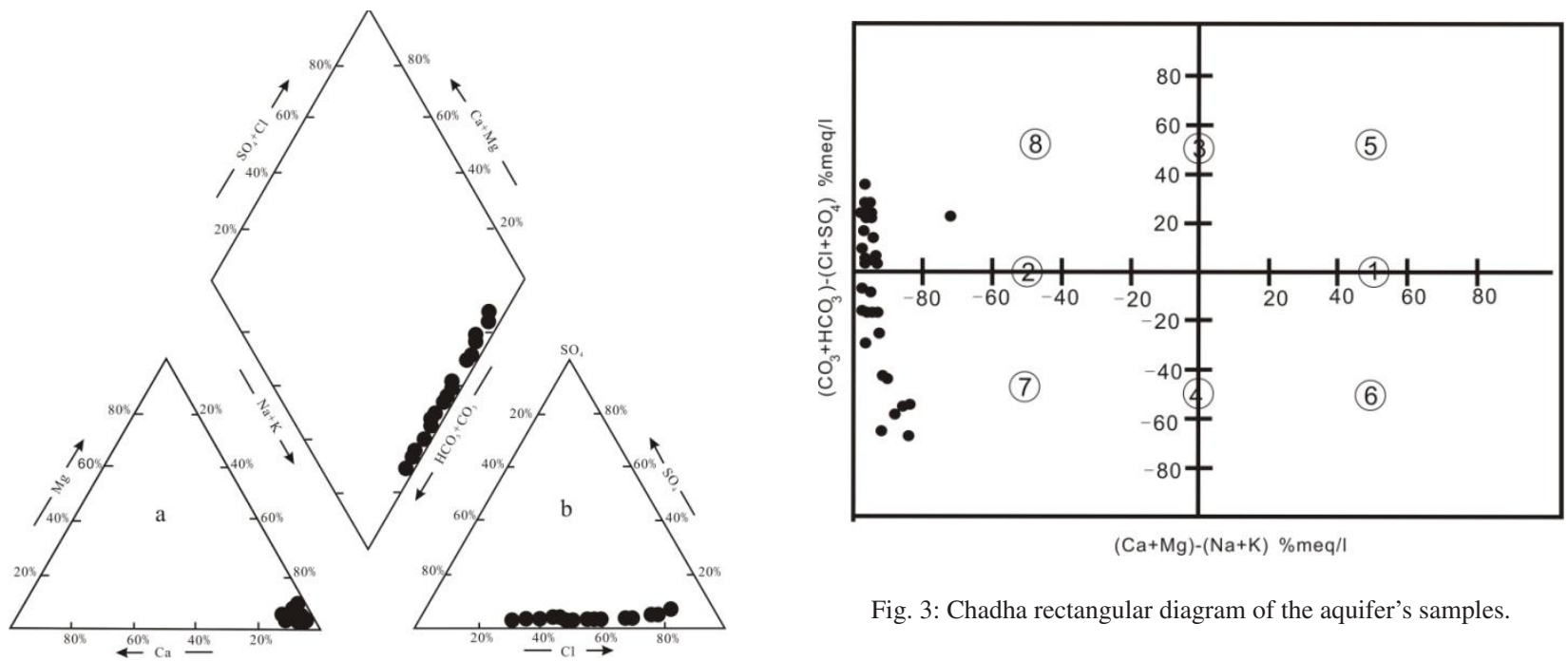

Fig. 3: Chadha rectangular diagram of the aquifer's samples.

Fig. 2: Piper diagram of the aquifer's samples.
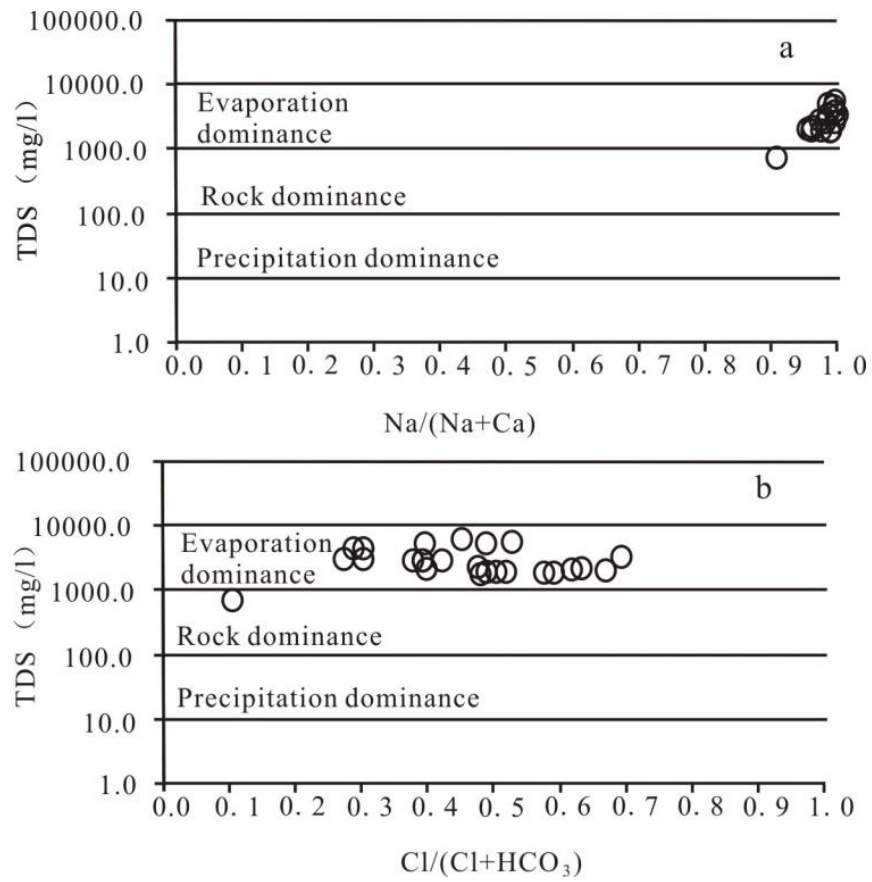

Fig. 4: Gibbs diagrams: a TDS verus $\mathrm{Na} /(\mathrm{Na}+\mathrm{Ca})$, b TDS verus $\mathrm{Cl} /\left(\mathrm{Cl}+\mathrm{HCO}_{3}\right)$.

diagram. However, all points are under the 1:1 line (Fig. 5a), showing that $\mathrm{Na}^{+}$content exceeds $\mathrm{Cl}$ in the samples. Excessive $\mathrm{Na}^{+}$can be acquired from cation exchange and/or the weathering of silicate minerals ( $\mathrm{Li}$ et al. 2018, Jalali 2007). The scatter plots of $\left(\mathrm{Ca}^{2+}+\mathrm{Mg}^{2+}\right)$ versus $\left(\mathrm{SO}_{4}{ }^{2-}+\mathrm{HCO}_{3}{ }^{-}\right)$and $\left(\mathrm{Ca}^{2+}+\mathrm{Mg}^{2+}-\mathrm{SO}_{4}{ }^{2-}-\mathrm{HCO}_{3}{ }^{-}\right)$versus $\left(\mathrm{Na}^{+}-\mathrm{Cl}^{-}\right)$further verify the above-mentioned two functions. Samples plotted on the $\left(\mathrm{Ca}^{2+}+\mathrm{Mg}^{2+}\right)$ versus $\left(\mathrm{SO}_{4}{ }^{2-}+\mathrm{HCO}_{3}{ }^{-}\right)$diagram fall under in the $\left(\mathrm{SO}_{4}{ }^{2-}+\mathrm{HCO}_{3}{ }^{-}\right)$area (Fig. 5b), suggesting that the dissolution of sulfate and the weathering of silicate are the main interaction in this process and redundant $\mathrm{Na}^{+}$can be obtained from the weathering of silicate minerals, such as albite. Meanwhile, excessive $\mathrm{Na}^{+}$can also be acquired from the cation exchange, the ratio of $\left(\mathrm{Ca}^{2+}+\mathrm{Mg}^{2+}-\mathrm{SO}_{4}{ }^{2-}-\mathrm{HCO}_{3}{ }^{-}\right)$ 

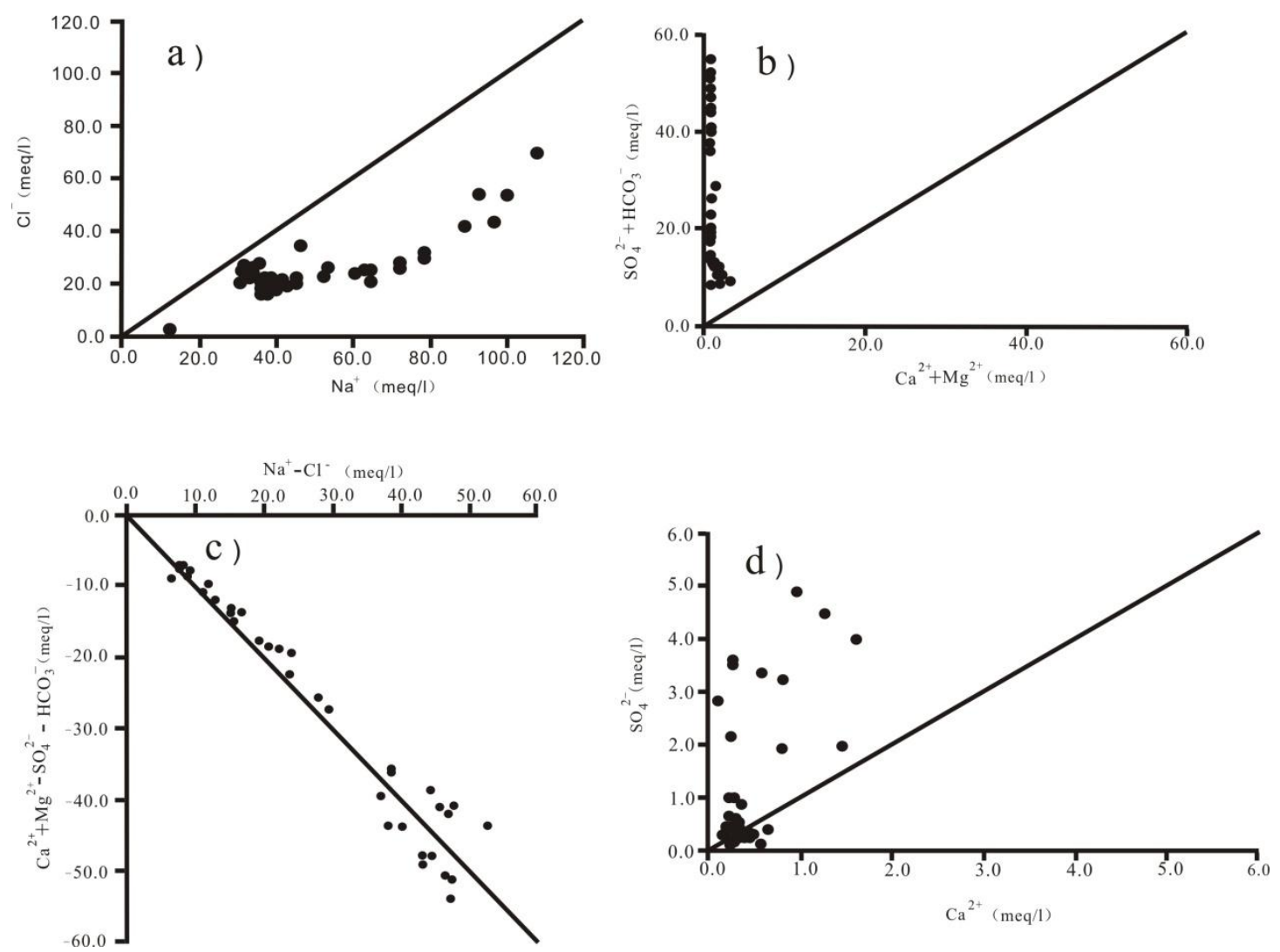

Fig. 5: Plots of (a) $\mathrm{Na}^{+}$versus $\mathrm{Cl}^{-}$; (b) $\left(\mathrm{Ca}^{2+}+\mathrm{Mg}^{2+}\right)$ versus $\left(\mathrm{SO}_{4}{ }^{2-}+\mathrm{HCO}_{3}^{-}\right)$; (C) $\left(\mathrm{Ca}^{2+}+\mathrm{Mg}^{2+}-\mathrm{SO}_{4}{ }^{2-}-\mathrm{HCO}_{3}{ }^{-}\right)$versus $\left(\mathrm{Na}^{+}-\mathrm{Cl}^{-}\right) ;($d $) \mathrm{Ca}^{2+}$ versus $\mathrm{SO}_{4}{ }^{2-}$.

$/\left(\mathrm{Na}^{+}-\mathrm{Cl}^{-}\right)$is plotted along and around the line of -1 (Fig. $\left.5 \mathrm{c}\right)$, which indicate that cation exchange also plays a vital role in the major hydrochemical process. The 1:1 ratio between $\mathrm{Ca}^{2+}$ and $\mathrm{SO}_{4}^{2-}$ proved the sole dissolution of sulfate, which is widespread in coal-bearing fractured aquifers. However, most scatters were above the 1:1 line (Fig. 5d), suggesting other water-rock interactions offered excessive sulfate anion, for instance, the oxidation of hydrogen sulfide during the mining period. The ratio of $\mathrm{Ca}^{2+} / \mathrm{Mg}^{2+}$ can be used to infer their origins, for example, dolomite dissolution with the ratio is 1 , calcite dissolution with the ratio is between 1 and 2 , while the silicate mineral dissolution and/or weathering with a ratio more than 2 (Varol \& Davraz 2014). The ratio of $\mathrm{Ca}^{2+} / \mathrm{Mg}^{2+}$ of the studied aquifer varied from 0.3 to 3.6. Three samples have a ratio of 1 indicating the dissolution of dolomite, and 11 samples with the ratio ranging from 1 to 2 characterize the dissolution of calcite, 13 samples have a ratio $>2$ which indicates the effect of silicate minerals. Nevertheless, due to the low concentration of $\mathrm{Ca}^{2+}$ and $\mathrm{Mg}^{2+}$, the dissolution of carbonate rocks plays a finite contribution to the solute composition.

\section{Principal Component Analysis/Factor Analysis}

The principal component /factor analysis (PCA/FA) with Varimax rotation was applied. Eigenvalues of 1.00 or greater were selected as the new variables. Factor loading with $>0.75$, 0.75-0.5, and 0.5-0.3 were classified as strong, moderate, and weak, respectively (Palma et al. 2010, Pejman et al. 2009). Two factors explained $70.25 \%$ of the variance were extracted, and the results of PCA/FA were summarized in Table 3. The first varifactor (VF1) accounted for $36.11 \%$ of the variance. Strong positive loading for $\mathrm{Ca}^{2+}$ and $\mathrm{Mg}^{2+}$, and moderate positive loading for $\mathrm{SO}_{4}{ }^{2-}$ represented the dissolution of sulfate. The second varifactor (VF2) explained $34.14 \%$ of the variance. VF2 exhibited strong positive loading for $\mathrm{Na}^{+}$and $\mathrm{Cl}^{-}$, and moderate positive loading for $\mathrm{HCO}_{3}^{-}$. VF2 was attributed to the dissolution of halite and the weathering of silicate.

\section{Cluster Analysis}

Cluster analysis is the method of grouping the variables into different clusters based on their similarities. In this study, a hierarchical cluster was performed by means of Ward's 
Table 3: Principal component analysis of the aquifer's hydrochemical variables.

\begin{tabular}{|c|c|c|c|c|}
\hline \multirow[t]{2}{*}{ component } & \multicolumn{2}{|c|}{ Before Rotation } & \multicolumn{2}{|c|}{ After Rotation } \\
\hline & FC1 & FC 2 & VF1 & VF2 \\
\hline $\mathrm{Ca}^{2+}$ & -0.74 & 0.52 & 0.89 & -0.12 \\
\hline $\mathrm{Mg}^{2+}$ & -0.80 & 0.45 & 0.89 & -0.22 \\
\hline $\mathrm{Na}^{+}$ & 0.86 & 0.48 & -0.30 & 0.94 \\
\hline $\mathrm{CO}_{3}{ }^{2-}$ & 0.37 & 0.12 & -0.19 & 0.34 \\
\hline $\mathrm{HCO}_{3}^{-}$ & 0.83 & 0.13 & -0.51 & 0.66 \\
\hline $\mathrm{Cl}^{-}$ & 0.58 & 0.72 & 0.07 & 0.92 \\
\hline $\mathrm{SO}_{4}^{2-}$ & -0.67 & 0.37 & 0.74 & -0.19 \\
\hline Eigen Values & 3.52 & 1.40 & 2.53 & 2.39 \\
\hline $\operatorname{Var} / \%$ & 50.30 & 19.95 & 36.11 & 34.14 \\
\hline Cum $/ \%$ & 50.30 & 70.25 & 36.11 & 70.25 \\
\hline
\end{tabular}

method using the squared Euclidean distances for similarity measure (Kamble \& Vijay 2011). A total of 40 samples are used for cluster analysis, and a dendrogram with two significant clusters is composed as shown in Fig. 6. Cluster 1 includes $\mathrm{Na}^{+}, \mathrm{HCO}_{3}^{-}, \mathrm{Cl}^{-}$and $\mathrm{CO}_{3}{ }^{2-}$, these components are related to the dissolution of halite and the weathering of silicate minerals. Cluster 2 comprised $\mathrm{Ca}^{2+}, \mathrm{Mg}^{2+}$ and $\mathrm{SO}_{4}{ }^{2-}$, which implies the dissolution of sulfate minerals, such as gypsum and magnesium sulfate.

\section{WATER QUALITY ASSESSMENT}

\section{Drinking assessment}

The pumped coal-bearing fractured water can be converted into groundwater by infiltration, and the quality of the subsurface water will affect human health. In comparison to the standard limit proposed by WHO (2011) which is listed in Table 4 (Talib et al. 2019), all of $\mathrm{Ca}^{2+}, \mathrm{Mg}^{2+}$ and $\mathrm{SO}_{4}{ }^{2-}$ contents are below the limit, showing the suitability for drinking. Whereas the concentration of $\mathrm{Na}^{+}$and $\mathrm{HCO}_{3}{ }^{-}$are all above the limit, and some samples show more than ten times than the WHO standard. The majority of $\mathrm{Cl}^{-}$, TDS and $\mathrm{pH}$ values

Table 4: Weight and relative weight of each chemical parameter.

\begin{tabular}{|llll|}
\hline Chemical parameters & WHO Standard $(2011)$ & Weight $\left(w_{\mathrm{i}}\right)$ & Relative weight $\left(\mathrm{W}_{\mathrm{i}}\right)$ \\
\hline $\mathrm{Ca}^{2+}$ & 200 & 3 & 0.103 \\
$\mathrm{Mg}^{2+}$ & 150 & 3 & 0.103 \\
$\mathrm{Na}^{+}$ & 200 & 4 & 0.138 \\
$\mathrm{HCO}_{3}^{-}$ & 250 & 1 & 0.034 \\
$\mathrm{Cl}^{-}$ & 250 & 5 & 0.173 \\
$\mathrm{SO}_{4}^{2-}$ & 250 & 5 & 0.173 \\
$\mathrm{TDS}^{2-}$ & 1000 & 5 & 0.173 \\
$\mathrm{pH}$ & 8.5 & 3 & 0.103 \\
$/$ & $/$ & $\sum=29$ & $\sum=1$ \\
\hline
\end{tabular}

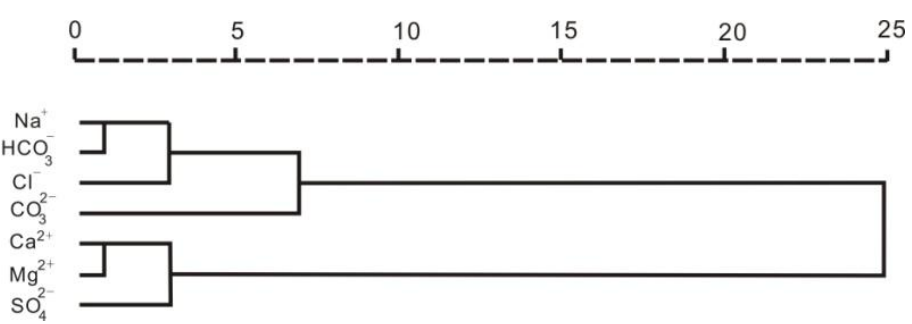

Fig. 6: Cluster analysis of the aquifer's hydrochemical variables. 
exceed the WHO standard, which indicates that these indices are inadequate for drinking purposes and even lead to a series of diseases such as hypertension, renal failure, etc.

The water quality index (WQI) is well-suited for classification and appraisal for drinking purposes, with the advantages of converting a large number of water quality data into a single value (Talib et al. 2019, Kumar \& James 2013). Three calculation steps are as follows: (1) The first step involves the relative weight calculation. Based on the importance to the water quality, eight parameters (TDS, $\mathrm{SO}_{4}{ }^{2-}, \mathrm{Cl}^{-}, \mathrm{Na}^{+}, \mathrm{Ca}^{2+}$, $\mathrm{Mg}^{2+}, \mathrm{pH}$, and $\mathrm{HCO}_{3}{ }^{-}$) have been given the assigned weight between 1 and 5 according to its importance. (2) The second step is the calculation of quality rating for each parameter, and the WHO standard is listed in Table 4. (3) The third step is the calculation of the water quality index.

The calculated WQI values can be classified as excellent $(<50)$, good (50-100), poor (100-200), very poor (200300 ), and unsuitable (>300) for human consumption. The computed WQI values are summarized in Table 5, and the values vary from 73.9 to 504.8. None of the samples fall under the excellent, $2.5 \%$ of the samples represent "good water", $37.5 \%$ show "poor water", $27.5 \%$ indicate "very poor", and $32.5 \%$ exhibit "unsuitable water", which suggest that these samples are not suitable for direct drinking. Hence, prior to drinking, thorough water quality treatment measures and the environmental monitoring system need to be conducted to ensure the discharged water reaching the emission standard.

\section{Irrigation assessment}

High salinity and strong alkalinity will lead to a harmful effect on crop growth and yields. The indices used for irrigation appraisal mainly contain sodium adsorption ratio (SAR), $\% \mathrm{Na}$, and residual sodium carbonate (RSC) (Berhe 2020, Adimalla et al.2018, Kaur et al. 2017). The classification criteria of irrigation water quality were summarized in Table 6. SAR, which indicates the content of sodium in irrigation water or soil solution, is the most general parameter for appraising the degree of soil alkalization. $\% \mathrm{Na}$ is used for representing the risk of alkali hazard caused by irrigation water, and high content can reduce the permeability and poor drainage of the soil. RSC is employed to assess alkali damage degree, and the negative RSC indicates that there is no excess carbonate to react with $\mathrm{Na}^{+}$, so it will not increase alkali damage. On the contrary, positive RSC can bring out alkali damage to the water.

As given in Table 7, the SAR value ranges within 12.6214.1 with a mean of 106.9 , indicating that all of the samples are unacceptable for irrigation. Only one sample with a SAR of 12.6 is good for irrigation. The computed $\% \mathrm{Na}$ of the present study's samples ranges from 86.7-99.7 with an average of 98.0, suggesting that the aquifer is unsuitable for irrigation. The calculated RSC values are in the range of $3.7-53.4$ with a mean of 28.2 , and $100 \%$ of the samples are classified into unsuitable categories for irrigation purposes.

Overall, the samples of the aquifer are generally unsuitable for irrigation. Long-term utilization of this aquifer water may give a rise to sodium hazards and affect crop growth and yields. Therefore, centralized treatment and discharge should be implemented before irrigation to ensure regional sustainable development.

\section{CONCLUSIONS}

Coal-bearing fractured aquifer is regarded as one of the most

Table 5: Classification of the aquifer's samples according to WQI.

\begin{tabular}{|lllll|}
\hline Calculated value & & Threshold & No. of samples & Percentage (\%) \\
\hline Min & 73.9 & $<50$ & 0 & 0 \\
& & $50-100$ & 1 & 2.5 \\
Max & 504.8 & $100-200$ & 15 & 37.5 \\
& & $200-300$ & 11 & 27.5 \\
Mean & 257.0 & $>300$ & 13 & 32.5 \\
\hline
\end{tabular}

Table 6: Classification criteria of irrigation water quality based on SAR, \% Na, and RSC.

\begin{tabular}{|lllll|}
\hline SAR & Irrigation water quality & $\% \mathrm{Na}$ & $\mathrm{RSC}$ & Irrigation water quality \\
\hline$<10$ & Excellent quality & $<30$ & $<1.25$ & Suitable \\
$10-18$ & Good quality & $30-60$ & $1.25-2.5$ & Marginally suitable \\
$18-26$ & Acceptable quality & $>60$ & $>2.5$ & Unsuitable \\
$>26$ & Unacceptable quality & - & - & - \\
\hline
\end{tabular}


Table 7: Results of irrigation water quality assessment.

\begin{tabular}{|llll|}
\hline & SAR & $\% \mathrm{Na}$ & RSC \\
\hline Min & 12.60 & 86.70 & 3.70 \\
Max & 214.10 & 99.70 & 53.40 \\
Mean & 106.90 & 98.00 & 28.20 \\
\hline
\end{tabular}

dynamic mine water inrush sources, and it can be used for irrigation and even reserved drinking water sources after effective and safe treatment. In the present study, hydrochemical characteristics, ion source, and water quality evaluation with respect to drinking and irrigation of the coal-bearing fractured aquifer in Dingji coal mine, Huainan coalfield, China were discussed in detail. The results showed that the relative order of major ion composition was $\mathrm{Na}^{+}>\mathrm{Ca}^{2+}>$ $\mathrm{Mg}^{2+}$ for cations, and $\mathrm{HCO}_{3}{ }^{-}>\mathrm{Cl}^{-}>\mathrm{SO}_{4}{ }^{2-}>\mathrm{CO}_{3}{ }^{2-}$ for anions, respectively. Piper diagram and $\mathrm{Chadha}$ rectangular diagram demonstrated the main hydrochemical facies are Cl-Na type and $\mathrm{HCO}_{3}{ }^{-} \mathrm{Na}$ type. Gibbs diagram, bivariate diagrams, and multivariate statistical analysis suggest that water-rock interactions of the aquifer include the dissolution of halite, sulfate, and carbonate, the weathering of silicate and cation exchange, etc. The computed WQI values vary from 73.9 to 504.8, and none of the samples fall under the excellent, $2.5 \%$ of the samples represent "good water", $37.5 \%$ show "poor water", $27.5 \%$ indicate "very poor", and $32.5 \%$ exhibit "unsuitable water". According to SAR, \% Na and RSC, the samples of the aquifer are generally unsuitable for irrigation. Long-term water quality monitoring should be carried out to dynamically grasp the variation and deal with it in time.

\section{ACKNOWLEDGMENTS}

This research was supported by the Excellent Top-Notch Talents Cultivation Foundation of Colleges and Universities, Anhui Province, China (gxbjZD2020091, gxyqZD2020047, gxgnfx2020106, and gxgnfx2020107), the Natural Science Research Foundation of Colleges and Universities, Anhui Province, China (KJ2019A0677 and KJ2019A0667), the Science Project of Suzhou University, Anhui Province, China (2019yzd01 and 2016ykf02), and the Doctoral Research Foundation of Suzhou University, Anhui Province, China (2017jb01).

\section{REFERENCES}

Ahmad, S., Umar, R. and Arshad, I. 2019. Groundwater quality appraisal and its hydrogeochemical characterization - Mathura City, Western Uttar Pradesh. J. Geol. Soc. India, 94: 611-623.

Adimalla, N., Li, P. and Venkatayogi, S. 2018. Hydrogeochemical evaluation of groundwater quality for drinking and irrigation purposes and integrated interpretation with water quality index studies. Environ. Process, 5: 363-383.
Berhe, B.A. 2020. Evaluation of groundwater and surface water quality suitability for drinking and agricultural purposes in Kombolcha town area, eastern Amhara region, Ethiopia. Appl. Water Sci., 10: 127-143.

El Alfy, M., Abdalla F., Moubark, K. and Alharbi, T. 2019. Hydrochemical equilibrium and statistical approaches as effective tools for identifying groundwater evolution and pollution sources in arid areas. Geosci. J., 23: 299-314.

Gui, H. and Lin, M. 2016. Types of water hazards in China coalmines and regional characteristics. Nat. Hazards., 84: 1501-1512.

Gu, D. 2015. Theory framework and technological system of coal mine underground reservoir. J. China Coal Society, 40(2): 239-246. (in Chinese).

Jiang, S., Huang, J., Xu, Z., Sun, Y., Liu, Q., Zhang, L. and Cui, L. 2018. Feasibility study of the construction of groundwater reservoir in the goaf of the Xuzhou Coal Mines. J. Eng. Geol. Hydrogeol., 45(5): 1723. (in Chinese)

Jalali, M. 2007. Hydrochemical Identification of Groundwater Resources and Their Changes under the Impacts of Human Activity in the Chah Basin in Western Iran. Environ. Monit. Assess., 130: 347-364.

Kaur, T., Bhardwaj, R. and Arora, S. 2017. Assessment of groundwater quality for drinking and irrigation purposes using hydrochemical studies in Malwa region, southwestern part of Punjab, India. Appl. Water Sci., 7: 3301-3316.

Kumar, P.J.S. and James, E.J. 2013. Development of water quality index (WQI) model for the groundwater in Tirupur district, South India. Chin. J. Geochem., 32: 261-268.

Kamble, S.R. and Vijay, R. 2011. Assessment of water quality using cluster analysis in the coastal region of Mumbai, India. Environ. Monit. Assess., 178: 321-332.

Liu, J., Wang, H., Jin, D., Xu, F. and Zhao, C. 2020. Hydrochemical characteristics and evolution processes of karst groundwater in Carboniferous Taiyuan formation in the Pingdingshan coalfield. Environ. Earth Sci., 79: 151-164.

Li, P., Wu, J., Tian, R., He, S., He, X., Xue, C. and Zhang, K. 2018. Geochemistry, Hydraulic Connectivity and Quality Appraisal of Multilayered Groundwater in the Hongdunzi Coal Mine, Northwest China. Mine Water Environ., 37: 222-237.

Liu, G., Zheng, L., Qi, C. and Zhang, Y. 2007. Environmental geochemistry and health of fluorine in Chinese coals. Environ. Geol., 52: 1307-1313.

Mahato, M.K., Singh, P.K., Singh, A.K. and Tiwari, A.K. 2018. Assessment of hydrogeochemical processes and mine water suitability for domestic, irrigation, and industrial purposes in East Bokaro Coalfield, India. Mine Water Environ., 37: 493-504.

MT/T 672-1997. 1997. Ministry of Coal Industry of the People's Republic of China. Technical requirement for hydrochemistry approach in coal mine water control.

Palma, P., Alvarenga, P., Palma, V.L., Fernandes, R.M., Soares, A.M.V.M. and Barbosa, I.R. 2010. Assessment of anthropogenic sources of water pollution using multivariate statistical techniques: A case study of the Alqueva's reservoir, Portugal. Environ. Monit. Assess., 165: 539-552.

Pejman, A.H., Nabi Bidhendi, G.R., Karbassi, A.R., Mehrdadi, N. and Bidhendi, M.E. 2009. Evaluation of spatial and seasonal variations in surface water quality using multivariate statistical techniques. Int. J. Environ. Sci. Technol, 6(3) : 467-476. 
Shirke, K.D., Kadam, A. K. and Pawar, N.J. 2020. Temporal variations in hydro-geochemistry and potential health risk assessment of groundwater from lithological diversity of the semi-arid region, Western Gujarat, India. Appl. Water Sci., 10: 156-175.

Sun, Y., Chen, G., Xu, Z., Yuan, H., Zhang, Y., Zhou, L., Wang, X., Zhang, C. and Zheng, J. 2020. Research progress of water environment, treatment, and utilization in coal mining areas of China. Journal of China Coal Soc., 45(1): 304-316. (in Chinese)

Talib, M.A., Tang, Z., Shahab, A., Siddique, J., Faheem, M. and Fatima, M. 2019. Hydrogeochemical Characterization and Suitability Assessment of Groundwater: A Case Study in Central Sindh, Pakistan. Int. J. Environ. Res. Public Health, 16: 886-906.

Varol, S. and Davraz, A. 2014. Assessment of geochemistry and hydrogeo- chemical processes in groundwater of the Tefenni plain (Burdur/Turkey). Environ. Earth Sci., 71: 4657-4673.

Wu, J., Zhou, H., He, S. and Zhang, Y. 2019. Comprehensive understanding of groundwater quality for domestic and agricultural purposes in terms of health risks in a coal mine area of the Ordos basin, north of the Chinese Loess plateau. Environ Earth Sci., 78: 446-462.

Zhang, S., Wang, H., He, X., Guo, S., Xia, Y., Zhou, Y., Liu, K. and Yang, S. 2020. Research progress, problems, and prospects of mine water treatment technology and resource utilization in China. Crit. Rev. Environ. Sci. Technol., 50(4): 331-383.

Zaki, S.R., Redwan, M., Masoud, A. and Abdel Monein, A.A. 2019. Chemical characteristics and assessment of groundwater quality in Halayieb area, the southeastern part of the Eastern Desert, Egypt. Geosci. J., 23, 149-164. 